\title{
Level of knowledge about basic life support of undergraduate students from the health area
}

\author{
Nível de conhecimento sobre suporte básico de vida entre formandos da área de saúde \\ Carlos Augusto Pelek ${ }^{1}$ (D) carlosaugustopelek@gmail.com

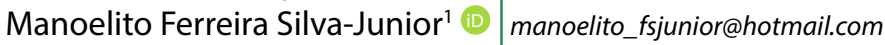 \\ Erildo Vicente Müller ${ }^{1}$ (D) erildomuller@hotmail.com
}

\begin{abstract}
Introduction: Basic Life Support (BLS) refers to the procedures that must be performed in situations of cardiorespiratory arrest or airway obstruction, and therefore, undergraduate students and health professionals must be highly trained to perform.

Objective: To determine the level of knowledge about Basic Life Support (BLS) and the associated factors among undergraduate students from the health area in their last year of school in a public university.

Methods: This is a cross-sectional study with undergraduate students in Physical Education, Nursing, Pharmacy, Medicine and Dentistry at the Universidade Estadual de Ponta Grossa, Brazil. Data collection was carried out in 2019, in the last month of course completion, by a trained researcher using a self-administered questionnaire containing sociodemographic data, professional training, perceived self-knowledge and a validated BLS instrument. There was an association between the outcome "undergraduate students' knowledge" dichotomized as high ( $\geq 70 \%$ correct) or low level ( $<70 \%$ correct) and the independent variables (sociodemographic data, professional training and perceived self-knowledge) and the performance of the binary and multinomial logistic regression $(p<0.05)$.
\end{abstract}

Results: 191 undergraduate students participated in the study, being $85.6 \%$ of the chosen universe. A total of 30 participants (15.7\%) had a high level of knowledge on BLS, being students from the Nursing $(n=12)$ and Medicine $(n=18)$ courses. While $35.3 \%$ of Nursing students and $46.2 \%$ of Medicine students had a high level of knowledge about BLS, there were no students from the Physical Education (0.0\%), Pharmacy (0.0\%) and Dentistry $(0.0 \%)$ courses. In the crude analysis, the low level of knowledge was associated with younger age $(\mathrm{OR}=2.75,95 \% \mathrm{Cl}: 1.22-6.21)$, not feeling safe to perform BLS $(\mathrm{OR}=3.12,95 \% \mathrm{Cl}: 1.38-7.01)$ and the fact that the discipline was not part of the undergraduate course $(\mathrm{OR}=18.35,95 \% \mathrm{Cl}: 2.44-$ 138.1). In the adjusted analysis, the fact that the discipline was not part of the undergraduate course (OR=13.41, 95\% Cl:1.74-103.12) remained.

Conclusion: Most students had a low level of knowledge about BLS, and only students from the Medicine and Nursing courses demonstrated a high level of knowledge. After adjustment, the fact that the discipline was not part of the undergraduate course was associated with a lower level of knowledge about BLS.

Keywords: Health Human Resource Training; Students, Health Occupations; Cardiopulmonary Resuscitation.

\section{RESUMO}

Introdução: O Suporte Básico de Vida (SBV) refere-se aos procedimentos que devem ser realizados em situações de parada cardiorrespiratória ou obstrução de via aérea, e, por isso, os acadêmicos e profissionais de saúde devem estar altamente capacitados para realização.

Objetivo: Determinar o nível de conhecimento sobre SBV e os fatores associados entre formandos dos cursos da área de saúde de uma universidade pública.

Método: Trata-se de um estudo transversal realizado com formandos de Educação Física, Enfermagem, Farmácia, Medicina e Odontologia da Universidade Estadual de Ponta Grossa. A coleta de dados foi realizada em 2019, no último mês de integralização curricular, por um pesquisador treinado com uso de questionário autoaplicado contendo dados sociodemográficas, formação profissional, autoconhecimento percebido e um instrumento validado de SBV. Houve associação entre o desfecho "conhecimento dos formandos" dicotomizado em alto ( $\geq 70 \%$ de acerto) ou baixo nível (< $70 \%$ de acerto) e as variáveis independentes (sociodemográficas, formação profissional e autoconhecimento percebido) e realização de regressão logística binária e multinomial $(p<0,05)$.

Resultados: Participaram do estudo 191 formandos, sendo 85,6\% do universo eleito. Um total de 30 participantes (15,7\%) apresentaram alto nível de conhecimento em SBV, sendo formandos do curso de Enfermagem $(n=12)$ e Medicina $(n=18)$. Enquanto $35,3 \%$ dos formandos de Enfermagem e 46,2\% de Medicina apresentaram alto nível de conhecimento sobre SBV, não houve nenhum formando de Educação Física (0,0\%), Farmácia (0,0\%) e Odontologia (0,0\%). Na análise bruta, o baixo nível de conhecimento foi associado com menor idade (OR=2,75; IC95\%: 1,22-6,21), não se sentir seguro para realizar o SBV $(O R=3,12$; IC95\%: 1,38-7,01) e não ter disciplina na graduação $(O R=18,35 ;$ IC95\%: 2,44-138,1). Na análise ajustada, manteve-se não ter disciplina na graduação (OR=13,41; IC95\%: 1,74-103,12).

Conclusão: A maioria dos formandos apresentou baixo nível de conhecimento sobre SBV, e apenas formandos em Medicina e Enfermagem demonstraram alto nível de conhecimento. Após ajuste, não ter realizado disciplina sobre a temática foi associado ao menor conhecimento sobre SBV.

Palavras-chave: Capacitação de Recursos Humanos em Saúde; Estudantes de Ciências da Saúde; Reanimação Cardiopulmonar.

1 Universidade Estadual de Ponta Grossa, Ponta Grossa, Paraná, Brazil.

Chief Editor: Rosiane Viana Zuza Diniz ～| Associate editor: Pedro Tadao Hamamoto Filho

Received on 11/09/20; Accepted on 03/12/21. | Evaluated by double blind review process. 


\section{INTRODUCTION}

Cardiovascular diseases represent the main cause of death worldwide: more people die annually from these diseases than from any other cause. It is estimated that 17.7 million people died from cardiovascular diseases in 2015, representing $31 \%$ of all deaths at global level'. Among the main causes of Cardiorespiratory Arrest (CRA) are acute myocardial infarction, coronary heart disease and cardiac arrhythmias. In Brazil, between 2004 and 2014, 8.8\% of deaths were due to myocardial infarction, angina and other ischemic heart diseases ${ }^{2}$.

External causes, such as traffic accidents, stab wounds or firearm injuries and airway obstruction by foreign bodies are also factors that can lead to CRA. They represent the second leading cause of death in Brazil in general terms, and the most important cause in the age group ranging from 1 to 49 years 3 . In the country, it is estimated that in 2019 more than 140,000 deaths occurred due to external causes ${ }^{4}$.

Basic Life Support (BLS) refers to the procedures that healthcare professionals must perform on patients in situations of CRA or airway obstruction. Cardiopulmonary resuscitation (CPR) is at the core of the BLS and consists in the set of performed maneuvers aiming at artificially maintaining arterial flow to the brain and other vital organs, until the spontaneous circulation resumes ${ }^{5}$.

CPR success depends on theoretical knowledge and also on psychomotor skills by the professionals who perform it, such as using the automated external defibrillator (AED) or adopting actions to clear the airway, among other possible measures ${ }^{6}$. The time factor is a determining variable, considering that any delay in treatment can result in sequelae and have an impact on patient survival ${ }^{7}$. Therefore, the training of health professionals in immediate and standardized care for this clinical situation can have favorable prognostic implications ${ }^{8}$.

Undergraduate courses in the health area are beneficial environments for the training of human resources prepared to deal with BLS. However, studies have shown a low level of knowledge about BLS in analyses by students from specific courses, such as Medicine ${ }^{9}$ or Nursing ${ }^{10}$, or in the comparative analysis between several courses in the health field ${ }^{11,12}$. The low level of knowledge has been associated mainly with the lack of prior BLS training among students ${ }^{9,12}$, and among professionals with little clinical experience ${ }^{13,14}$. Most of the studies have as their target-populations students from different periods ${ }^{9,12,15}$, interns $^{11}$ or professionals ${ }^{13,14,16,17}$, and little emphasis has been placed on the undergraduate students from different courses in the health area. In this context, the present study aimed to determine the level of knowledge about BLS and the associated factors in undergraduate students attending health courses in a public university.

\section{MATERIAL AND METHOD}

\section{Design and ethical aspects}

This research was a cross-sectional study with a quantitative approach, carried out with undergraduate students from health courses (Physical Education, Nursing, Pharmacy, Medicine and Dentistry) at Universidade Estadual de Ponta Grossa (UEPG), Paraná, Brazil. The study was previously approved by the Research Ethics Committee of UEPG, with the protocol of the Certificate of Presentation for Ethical Appreciation (CAAE) number 03813818.0.0000.0105.

\section{Study universe}

The study was carried out with undergraduate students from courses in the health area in 2019. The University has an yearly entry system for all evaluated courses, with the Medicine course ending in August and the remaining courses in December 2019.

The study universe was made available by the Undergraduate Students' Dean's Office, distributed as follows: Bachelor of Physical Education ( $n=44)$, Nursing $(n=35)$, Pharmacy $(n=41)$, Medicine $(n=46)$ and Dentistry $(n=57)$, totaling 223 eligible undergraduate students.

The inclusion criteria for the study were: being able to complete the health course in 2019; and agree to sign the Free and Informed Consent Form (ICF). The exclusion criteria were: having some unfinished discipline that would prevent the student from completing the course in 2019; students who took a break from College or dropped out of the course; or did not accept to participate in the study.

The bachelor's degree in Physical Education course at UEPG started in 2010, and the first version of the PoliticalPedagogical Project of the Course (PPC) is still used. The course lasts four years until course completion, with a minimum of 3,419 (three thousand, four hundred and nineteen) hours. The Nursing course at UEPG started in 2007. The fourth version of its PPC has been used since 2014, with five years until course completion, and a minimum of 4,800 (four thousand and eight hundred) hours. The bachelor's degree in Pharmacy at UEPG started in 1956, and the fifth version of its PPC has been used since 2005. The course lasts five years until course completion, with a minimum of 5,028 (five thousand and twenty-eight) hours. The Bachelor's Degree in Medicine at UEPG started in 2009. The PPC is in its second version and has been active since 2011. The course duration comprises a period of six years, with a minimum total of 8,258 (eight thousand, two hundred and fiftyeight) hours. The bachelor's degree in Dentistry at UEPG started in 1956 and the evaluated class was using the tenth version of the PPC, implemented in 2005. The PPC has a minimum total of 5,164 (five thousand one hundred and sixty-four) hours. 
The offer of a specific discipline that addresses the topic of Basic Life Support (BLS), it is described in the syllabus of disciplines of the courses of Physical Education, Nursing and Medicine. In the Physical Education course, there is a mandatory discipline called Hygiene Notions and Emergency Aid in Physical Education and Sports aimed at the specific professional training, with a 68-hour semester workload and a theoretical basis, and a semiannual offer in the first semester of the second academic year. In Nursing, there is a mandatory discipline of Emergency Nursing, aimed at the specific professional training of the course, with a workload of 68 hours, with a theoretical-practical basis, and a semiannual offer in the first semester of the fourth academic year. In the Medicine course, there are the disciplines of Internship in Surgical Urgency and Emergency and Internship in Clinical Urgency and Emergency, in the $5^{\text {th }}$ curricular year, which is mandatory, with a workload of 420 hours each and a theoretical-practical approach.

\section{Data collection}

Data collection was carried out at the institution itself, through a self-administered questionnaire at the end of the course completion, carried out in July 2019 for the Medicine course, and November and December 2019 for the Physical Education, Nursing, Pharmacy, and Dentistry courses. The tool was organized into two parts: the first included sociodemographic data, professional training, and perceived self-knowledge ${ }^{18}$, and the second part assessed the level of knowledge using an instrument validated in previous research ${ }^{12}$, containing 20 multiple-choice questions, each containing four answer choices.

\section{Variables}

The study outcome was the undergraduate students' level of knowledge, dichotomized according to the number of correct answers in 14 (70\%) of the 20 questions answered in the questionnaire: high (greater or equal than $70 \%$ of correct answers) or low ( $<70 \%$ of correct answers) level of knowledge about BLS. This cutoff was adopted considering the average grade for approval in the disciplines by the University. Although the calculation was based on the correct answers, we chose not to exclude the unanswered questions from the analysis and the latter were classified as 'not correct'.

The independent variables were divided as follows:

- Sociodemographic variables: sex (woman and man) and age (up to 24 years and 25 years or older).

- Professional training: undergraduate course (Physical Education, Nursing, Pharmacy, Medicine and Dentistry) and training for BLS (no and yes).

- Course duration in hours: more than 40h (no and yes) or more than 100 hours (no and yes), offer of a specific discipline in BLS/emergencies during undergraduate school (no and yes), completion of the discipline (no and yes), modality of the offered discipline (optional or mandatory), discipline approach (theoretical and theoretical-practical/ practical) and believing that the offered discipline was sufficient (no and yes).

- Perceived self-knowledge: feeling confident (no/ some situations and yes) and believing in the need to take courses (no and yes).

\section{Data analysis}

The data obtained were stored in a Microsoft Office Excel spreadsheet, and subsequently analyzed using the Statistical Package for the Social Science (SPSS) version 20.0 (IBM Corp., NY, United States). Descriptive statistics was performed using absolute ( $\mathrm{n}$ ) and relative (\%) frequencies. For the association between the study outcome (high and low knowledge) and the independent variables (sociodemographic data, professional training and perceived self-knowledge), Fisher's exact test or the Chi-square test was used ( $p<0.05$ ). The regression was performed using a binary logistic model (crude) and multinomial logistic model (adjusted) ( $p$ <0.05), which used 'high knowledge' as the reference category.

\section{RESULTS}

The study was carried out with 191 undergraduate students, totaling $85.6 \%$ of the chosen universe that met the eligibility criteria, with a proportion of participation per course of 37 undergraduate students from the Physical Education course (84.1\%), 34 from Nursing (97.1\%), 33 from Pharmacy (80.5\%), 39 from Medicine (84.8\%) and 48 from Dentistry (84.2\%) (Table 1).

Chart 1 shows that the highest proportion of correct answers was $40 \%$ (11.5\%) of the BLS questionnaire, followed by $35 \%$ and $65 \%$, with $9.4 \%$ among the undergraduate participants.

Chart 2 shows that the greatest number of incorrect answers occurred in Question 1 (90.6\%), which discussed the infant and child survival links, followed by Question 4 (64.9\%), regarding the CPR sequence after the diagnosis of CRA. The question with the highest number of correct answers was Question 10 (74.3\%), which was about the maneuver to be performed during the opening of airways, followed by Question 14 (69.1\%), about the use of the Automatic External Defibrillator (AED). 
Chart 1. Distribution of the proportion of correct answers on Basic Life Support among undergraduate students from health courses. Ponta-Grossa, PR, Brazil, 2019.

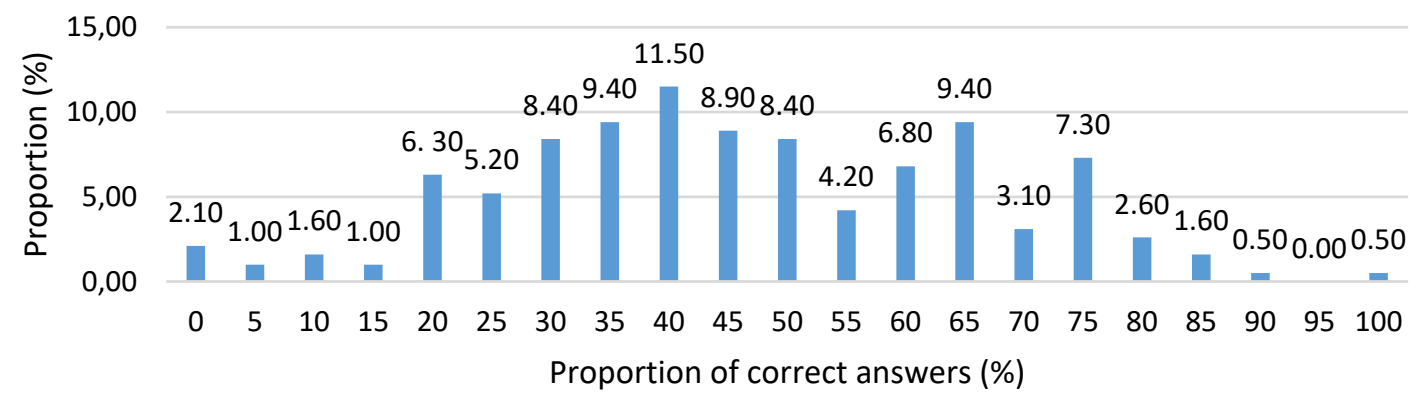

Chart 2. Distribution of errors, correct answers or no answers per question on Basic Life Support among undergraduate students from health courses. Ponta-Grossa, PR, Brazil, 2019.

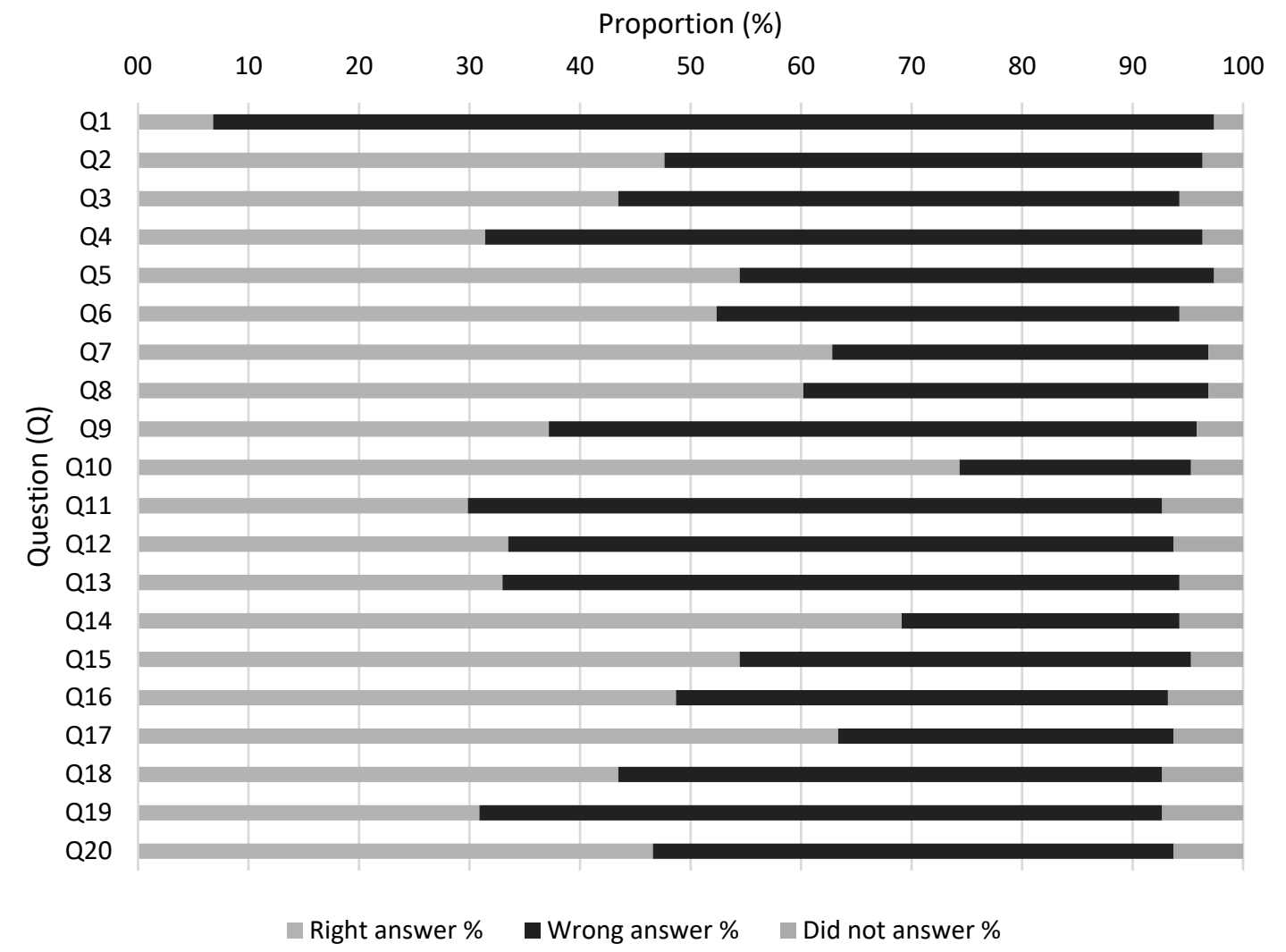

Table 1. Sample characterization and bivariate analysis between the level of knowledge about Basic Life Support and the health course attended by the undergraduate students. Ponta-Grossa, PR, Brazil, 2019.

\begin{tabular}{lcccc}
\hline \multirow{2}{*}{ Course } & \multicolumn{2}{c}{ Level of knowledge } & Total & p-value \\
\cline { 2 - 3 } & $\mathbf{n}(\%)$ & $\begin{array}{c}\text { High } \\
\mathbf{n}(\%)\end{array}$ & $\mathbf{n}(\%)$ & $34(17.8)$ \\
\hline Nursing & $22(13.7)$ & $12(40.0)$ & $37(19.4)$ & \\
Physical education & $37(23.0)$ & $0(0.0)$ & $33(17.3)$ & $<0.001$ \\
Pharmacy & $33(20.5)$ & $0(0.0)$ & $39(20.4)$ & \\
Medicine & $21(13.0)$ & $18(60.0)$ & $48(25.1)$ & \\
Dentistry & $48(29.8)$ & $0(0.0)$ & $191(100.0)$ & \\
\hline Total & $161(100.0)$ & $30(100.0)$ & & \\
\hline
\end{tabular}


A total of 30 participants (15.7\%) showed knowledge that was greater than $70 \%$, considered in the study as high knowledge about BLS. The highest level of knowledge about BLS was associated with the Medicine and Nursing courses ( $p<0.001$ ). While $35.3 \%$ of Nursing and $46.2 \%$ of Medical undergraduate students had a high level of knowledge about BLS, none of the Physical Education, Pharmacy and Dentistry students showed sufficient knowledge (Table 1).

Table 2 shows the sample characterization and the bivariate analysis. It was verified that the majority of the participants were females (64.9\%), aged up to 24 years (74.9\%). Of the participants, $64.6 \%$ were confident in performing first aid care, $63.3 \%$ affirmed they had previous extracurricular training and $66.8 \%$ confirmed the offer of the discipline (related to the topic. The majority considered the discipline to be insufficient (60.2\%) and manifested the need to perform new courses within the topic (90.0\%).

In the crude analysis, there was a greater chance of having a low level of knowledge on BLS among younger undergraduate students (OR $=2.75 ; 95 \% \mathrm{Cl}$ : 1.22-6.21), those who did not feel confident to perform BLS (OR=3,12;95\% Cl: 1.38-7.01) and those who did not have an offer for attending the discipline during undergraduate school (OR $=18.35 ; 95 \%$ Cl: 2.44-138.1). After adjustment, only not having had an offer for attending the discipline during undergraduate school was associated with a low level of knowledge about BLS (OR $=13.41$; 95\% Cl: 1.74-103.12) (Table 3).

Table 2. Sample characterization and bivariate analysis between the level of knowledge about Basic Life Support and independent variables among undergraduate students from health courses. Ponta-Grossa, PR, Brazil, 2019.

\begin{tabular}{|c|c|c|c|c|c|}
\hline \multirow[b]{2}{*}{ Variables } & \multirow[b]{2}{*}{ Categories } & \multicolumn{3}{|c|}{ Level of knowledge } & \multirow[b]{2}{*}{ p-value } \\
\hline & & $\begin{array}{l}\text { Low } \\
\text { n (\%) }\end{array}$ & $\begin{array}{l}\text { High } \\
\text { n (\%) }\end{array}$ & $\begin{array}{l}\text { Total } \\
\text { n (\%) }\end{array}$ & \\
\hline \multirow{2}{*}{ Sex } & Woman & $104(64.6)$ & $20(66.7)$ & $124(64.9)$ & \multirow{2}{*}{0.827} \\
\hline & Man & $57(35.4)$ & $10(33.3)$ & $67(35.1)$ & \\
\hline \multirow{2}{*}{ Age } & Up to 24 years & $126(78.3)$ & $17(56.7)$ & $143(74.9)$ & \multirow[t]{2}{*}{0.012} \\
\hline & 25 years or more & $35(21.7)$ & $13(43.3)$ & $48(25.1)$ & \\
\hline \multirow{2}{*}{ Feels confident } & No / some situations & $110(68.8)$ & $12(41.4)$ & $122(64.6)$ & \multirow[t]{2}{*}{0.005} \\
\hline & Yes & $50(31.2)$ & $17(58.6)$ & $67(35.4)$ & \\
\hline \multirow{2}{*}{ Received training } & No & $58(36.7)$ & $11(36.7)$ & $69(36.7)$ & \multirow[t]{2}{*}{0.996} \\
\hline & Yes & $100(63.3)$ & $19(63.3)$ & $119(63.3)$ & \\
\hline \multirow{2}{*}{ Attended a course with more than 100 hours } & No & $69(90.8)$ & $10(90.9)$ & $79(90.8)$ & \multirow[t]{2}{*}{0.999} \\
\hline & Yes & $7(9.2)$ & $1(9.1)$ & $8(9.2)$ & \\
\hline \multirow{2}{*}{ Attended a course with more than 40 hours } & No & $36(47.4)$ & $6(54.5)$ & $42(48.3)$ & \multirow[t]{2}{*}{0.656} \\
\hline & Yes & $40(52.6)$ & $5(45.5)$ & $45(51.7)$ & \\
\hline \multirow{2}{*}{ Undergraduate discipline was offered } & No & $62(38.8)$ & $1(3.3)$ & $63(33.2)$ & \multirow[t]{2}{*}{$<0.001$} \\
\hline & Yes & $98(61.3)$ & $29(96.7)$ & $127(66.8)$ & \\
\hline \multirow{2}{*}{ Type of discipline offered } & Optional & $6(6.4)$ & $2(6.9)$ & $8(6.5)$ & \multirow[t]{2}{*}{0.922} \\
\hline & Mandatory & $88(93.6)$ & $27(93.1)$ & $115(93.5)$ & \\
\hline \multirow{2}{*}{ Attended the discipline } & No & $1(14.3)$ & $0(0.0)$ & $1(11.1)$ & \multirow[t]{2}{*}{0.571} \\
\hline & Yes & $6(85.7)$ & $2(100)$ & $8(88.9)$ & \\
\hline \multirow{2}{*}{$\begin{array}{l}\text { Believes that the discipline offered was } \\
\text { sufficient }\end{array}$} & No & $55(60.4)$ & $16(59.3)$ & $71(60.2)$ & \multirow[t]{2}{*}{0.912} \\
\hline & Yes & $36(39.6)$ & $11(40.7)$ & $47(39.8)$ & \\
\hline \multirow[b]{2}{*}{ Method of discipline approach } & Theoretical & $5(5.4)$ & $3(10.7)$ & $8(6.6)$ & \multirow[t]{2}{*}{0.319} \\
\hline & $\begin{array}{c}\text { Theoretical-practical/ } \\
\text { practical }\end{array}$ & $88(94.6)$ & $25(89.3)$ & $113(93.4)$ & \\
\hline \multirow{2}{*}{ Believes in the need for extra courses } & No & $17(10.6)$ & $2(6.7)$ & $19(10.0)$ & \multirow[t]{2}{*}{0.507} \\
\hline & Yes & $143(89.4)$ & $28(93.3)$ & $171(90.0)$ & \\
\hline
\end{tabular}


Table 3. Analysis of crude and adjusted associations between the low level of knowledge about Basic Life Support and independent variables among undergraduate students from health courses. Ponta-Grossa, PR, Brazil, 2019.

\begin{tabular}{|c|c|c|c|c|}
\hline \multirow[b]{2}{*}{ Variables } & \multicolumn{3}{|c|}{ Low Level of Knowledge } & \multirow[b]{2}{*}{ p-value } \\
\hline & $\mathrm{OR}^{\mathrm{a}}(95 \% \mathrm{Cl})$ & $p$-value & $\mathrm{OR}^{\mathrm{b}}(95 \% \mathrm{Cl})$ & \\
\hline \multicolumn{5}{|l|}{ Age } \\
\hline 25 years or more & 1.00 & & 1.00 & \\
\hline Up to 24 years & $2.75(1.22-6.21)$ & 0.015 & $1.76(0.74-4.21)$ & 0.197 \\
\hline \multicolumn{5}{|l|}{ Feels confident } \\
\hline Yes & 1.00 & & 1.00 & \\
\hline No/Some situations & $3.12(1.38-7.01)$ & 0.006 & $2.26(0.97-5.29)$ & 0.600 \\
\hline \multicolumn{5}{|l|}{ Undergraduate course offer } \\
\hline Yes & 1.00 & & 1.00 & \\
\hline No & $18.35(2.44-138.1)$ & 0.005 & $13.41(1.74-103.12)$ & 0.013 \\
\hline
\end{tabular}

${ }^{a}$ Crude Odds Ratio. ${ }^{b}$ Adjusted Odds Ratio.

* The variable 'training course', despite being statistically different in the bivariate analysis, was not used in the regression, because there were no correct answers among some of the analyzed courses.

\section{DISCUSSION}

In the present study, the majority of the undergraduate students from the health area in the present study showed a low level of knowledge about BLS, especially those from the Physical Education, Pharmacy and Dentistry courses. In the literature, other studies have shown the low level of knowledge about BLS among students $9,10,12$, whether in studies with greater stringency regarding the proportion of correct answers in the definition of high and/or low knowledge about BLS, such as $84 \%^{12}$ or $50 \%{ }^{9}$. The literature, shows a wide variation in the prevalence of correct answers, between $0.1 \%{ }^{12}$ and $13 \%$ among medical students ${ }^{9}$ and $25 \%$ for Nursing students ${ }^{10}$. The difference verified in the present study in relation to the national ${ }^{12}$ and international ${ }^{11}$ literature may have occurred to the instrument used, such as the variation in the content of questions to assess knowledge about BLS, or because of the professional training between the realities in each of the health area courses. Although the data from the study is related to undergraduate students, studies have verified the low performance also among professionals, in which $10.2 \%$ of the Doctors and Nurses of a public hospital had a high level of knowledge about BLS ${ }^{17}$.

The courses in Medicine and Nursing were the only ones that had undergraduate students with a high level of knowledge, as none of the students from the Physical Education, Pharmacy and Dentistry course had scores above $70.0 \%$. A study carried out with the same questionnaire in São Paulo showed similar data, with a higher level of knowledge among students in the medical course, followed by the Nursing course ${ }^{12}$. A study carried out in Saudi Arabia showed no difference in knowledge among the students of Medicine, Dentistry, Nursing and
Pharmacy courses ${ }^{11}$. The results in the present study showing a prevalence of high knowledge in students from the Medicine and Nursing courses in comparison with other studies ${ }^{9,11,12}$, may result from the analysis being carried out only with undergraduates, and not with students from different years after course completion. The results obtained in the present study, with a prevalence of high knowledge in the Medicine and Nursing courses in comparison with other studies $9,11,12$, might be due to the fact that the analysis was carried out with graduates only, and not with students from different years of the course completion period. Moreover, the higher performance among graduates of these courses may be associated with the offer of the discipline towards the end of the course completion, offered closer to the time of the internship, carried out mainly in a hospital environment, and, consequently, with a greater probability of using BLS practices in the academic routine. This reality becomes different in the Physical Education course, which, despite having the same workload when compared to the Nursing course, has a theoretical approach and occurs in the beginning of the course completion period, and there were no students with high knowledge. This aspect has been previously revised by the Dentistry course: the new PPC, in its $11^{\text {th }}$ version, active since 2016 , included the content in the discipline of Diagnosis and Oral Surgery III, offered in the third curricular year, with a workload of 136 hours and theoreticalpractical basis. Additionally, when considering a study with the eligibility of trained undergraduate students only, as in the present study, there is a greater gap between the moment the content is addressed in the discipline and the moment of data collection. The other courses, Pharmacy and Dentistry, did not have the BLS content in the menu of the offered disciplines, 
which can demonstrate the low knowledge. This aspect has already been revised by the Dentistry course, where the new PPC, in its eleventh version, which has been used since 2016, includes the content in the discipline of Diagnosis and Oral Surgery III, offered in the third curricular year with a workload of 136 hours, having a theoretical-practical approach.

The highest rates of correct answers were found in questions regarding the opening of airways and the use of the AED. Other studies also found a higher rate of correct answers regarding the question related to the opening of airways ${ }^{19}$ and a study with newly graduated doctors verified the same result regarding the use of $A E D^{13}$. A study carried out with Nursing professionals indicated a higher rate of correct answers in the question regarding the recognition of CRA and the initial management, but a higher number of incorrect answers in the question regarding the opening of airways and ventilation 16. The higher rate of correct answers in these subjects may be associated to the fact that they are more general topics and addressed in a more diffused manner.

In the present study, there were a greater number of incorrect answers in questions related to the links in the infant and child survival chain, and about the sequence of CPR after the diagnosis of CRA. The issues related to infants and children within the BLS were rarely addressed in the literature ${ }^{10}$, giving preference to procedures in adults, thus being the reason of the difficulty in comparing the findings in the present study. However, other studies have found a large proportion of incorrect answers in questions about the CPR sequence ${ }^{11,19}$. The difficulty in learning these subjects can be attributed to the lack of consistent and continuous study by the students.

In the crude analysis, age was an associated factor, where younger students had a lower level of knowledge about BLS. Other studies with undergraduate students showed that students attending more advanced periods of the courses obtained a higher number of correct answers ${ }^{12}$, as well as in a study with lay people in Portugal, where older age was associated with a higher level of knowledge ${ }^{20}$. Another study, also carried out with lay people carried out in the state of Minas Gerais, Brazil, did not verify this association ${ }^{21}$, as it was not verified between doctors and nurses ${ }^{17}$. The difference in results may be associated with the difference in methodology and the target audience participating in the study. Although older age does not necessarily imply greater knowledge, it is possible to assume that older people have had more opportunities to go through learning experiences or the practical need for its application, that is, age would not be a direct predictor, but the greater clinical professional experience, in studies with students or professionals in the area, or greater maturity among older individuals to deal with adverse situations, in the case of studies with lay people.
The fact that the present study considers courses with different course completion periods - for instance, the physical education course is completed in four years, while the medical course is completed in six years - might have interfered with the results. Additionally, considering that entering an educational institution generally occurs later due to the competitive entrance exam, the medical course may include older students. One must also consider the fact that Nursing students might have attended a technical course in the area. Based on these aspects, the results must be considered with care, as these variables are difficult to interpret. When the results were adjusted, there was no association with age in the final model.

In the crude analysis, another associated aspect was not feeling confident to perform the BLS and low knowledge. Moreover, an information verified here that needs to be explored was a minority of the undergraduate students feeling confident or able to perform emergency procedures, which demonstrates a priority necessity of training for these future professionals. A study with Nurses found a moderate positive correlation between the performance of BLS procedures and clinical experience $^{14}$ and a study with newly graduated physicians showed an association between longer time in clinical practice and greater confidence when performing $\mathrm{CPR}^{13}$. Therefore, in the present study, health education with a longer time in the hospital environment, as in Medicine and Nursing, including the internship, may result in students feeling more prepared to deal with BLS issues.

Failure to attending the BLS discipline during undergraduate school was associated with a low level of knowledge, both in crude and the adjusted analysis, and therefore, within the limitations of the present study, the inclusion of curricular disciplines seems to be the most appropriate way to train future health professionals in BLS. While the studies show an association of the level of knowledge with previous BLS courses ${ }^{9,12,16}$, this variable is not associated in the present study, either with training, courses with lower or higher workloads. This aspect may be the result of the low adherence to extracurricular courses by the participants in the present study, even though $90.0 \%$ affirmed that attending the courses is important. Several factors can explain this result: the involved cost, the methodology used in the courses, the fact that the course was non-mandatory, or the students' expectation regarding the possibility of the content being part of the curricular activities. Moreover, in Brazil, unfortunately there is no culture of preventive safety measures, with eventual and/or continuous simulations and/ or training for disasters of different kinds.

Therefore, the results of the present study demonstrated that the presence of a discipline offered in the PPC of the health 
area courses showed a greater impact on the level of knowledge than on the previously performed extracurricular courses. This may be associated with the fact that the disciplines have a workload distributed throughout a continuous teachinglearning process, rather than an eventual one, such as training courses. Moreover, the offer of curricular disciplines with evaluation activities that follow the standard for learning assessment may be more effective for students, since this methodology is less frequent in training courses.

Despite the contributions present in the study, some limitations should be highlighted, such as the methodological variability in the studies present in the literature and, therefore, difficulties for comparability. Different collection instruments were found to measure knowledge in BLS, which, although validated, were not the same ${ }^{11,12,20}$. Among these, the questionnaire by Tavares et al. ${ }^{12}$ was selected because it has been validated in Portuguese, applied to a sample containing different courses and has a large number of questions. The use of a questionnaire from another Brazilian study ${ }^{12}$ that achieved results that were similar to these presented here can reinforce the sensitivity of the questionnaire in measuring BLS and its reproducibility, even in samples from different locations, and thus, it seemed to be an adequate instrument to assess the knowledge. However, the study indicated a cutoff for the high level, with $84 \%^{22}$, a parameter considered high, in which a limited number of participants managed to reach this proportion. Therefore, considering the average grade for approval at the institution, it was decided to reduce the cutoff to $70 \%$, and the knowledge was considered appropriate.

Another aspect that must be clarified is the limitation of using a questionnaire to measure the level of knowledge in BLS. About the procedural content, an assessment at the cognitive level only, in the theoretical field, becomes a limited way to assess the problem. That is, if the results shown here at the cognitive level demonstrate a low level of knowledge, they could be even worse if practical tests were performed. However, the use of questionnaires is still the main method of assessing knowledge, whether due to its low cost and the fact that it is easy to apply in different places around the world, such as in Brazil ${ }^{12}$, Peru ${ }^{9}$, United Kingdom ${ }^{15}$, or Middle East ${ }^{11}$, being instruments based on guidelines about the subject and subsequently validated. However, the existence of a standardized and universal questionnaire would be important for better comparability of results in different population samples. Additionally, the performance of longitudinal studies, capable of involving the evolution of the students' knowledge throughout their training, is encouraged, to understand which moment of the training would be the ideal one to include the discipline about BLS. The use of data collection strategies that also included the verification of learning at a practical level could bring data more consistent with the reality about the participants' level of knowledge.

Another question to be considered in future studies is the measurement of the participation in extracurricular activities in the area of urgency/emergency, such as leagues, monitoring activities or continuing education projects in the area. This information could help to better understand the apprehended knowledge and promote greater interest in the topic according to the intended future specialty.

Moreover, the sample is another factor of difficult comparability. While some studies include only one health course as the study universe $e^{9,10,15}$, others considered several courses regardless of the semester or year ${ }^{11,12,19}$, while others carry out studies with health professionals that have already graduated $^{13,14,17}$ and even lay people ${ }^{20,21}$. The present study assessed undergraduate students only, aiming to reduce the memory bias and increase the reliability of measuring significant knowledge. In this sense, the data from the present study become a matter of concern, considering that before working in a specific area of each profession in the health field, undergraduate students need to understand that they are health professionals and, for this reason, they must be prepared to deal with emergency situations inside and outside health services. Therefore, integrality and interdisciplinarity must be an ever increasing part of the training of human resources in health.

When verifying that knowledge about BLS was not absorbed by most undergraduate students, that is, when they should be ready for the work market, this result reinforces the need to include permanent BLS discipline in HEls for all courses in the health area, and mainly including an adequate perspective for the common needs within each health professional's field of action, as well as review and refresher courses of knowledge for graduated professionals, since even though they have had the training, the lack of continuous applicability of the learned knowledge can over time reduce the ability to use the clinical procedures necessary in specific cases of BLS.

\section{CONCLUSION}

Most of the study participants demonstrated a low level of knowledge about BLS, and only the students from the Medicine and Nursing courses showed a high level of knowledge.

The low level of knowledge about BLS was associated with younger age, not feeling confident in performing BLS procedures and not having attended the discipline about the topic during the professional training. However, after the adjustment, only not having attended the discipline about the topic was associated with low knowledge about BLS. 


\section{AUTHORS' CONTRIBUTION}

Carlos Augusto Pelek participated in the study design, data collection, and writing of the manuscript. Manoelito Ferreira Silva-Junior participated in the study design, supervised all study phases, performed the data analysis and the final review of the manuscript. Erildo Vicente Müller participated in the study design and data analysis and performed the correction and final review of the manuscript.

\section{CONFLICTS OF INTEREST}

The authors declare no conflicts of interest in this study.

\section{FUNDING}

The authors declare no funding for this research.

\section{REFERENCES}

1. Organização Pan-Americana da Saúde. Doenças cardiovasculares. Opas; 2017 [access in 26 may 2019]. Available from: https://www.paho.org/ bra/index.php?option=com_content\&view=article\&id=5253:doencascardiovasculares\&ltemid $=1096$.

2. Sociedade Brasileira de Cardiologia. Cardiômetro. Mortes por doenças cardiovasculares no Brasil: 2015 [acesso em 26 maio 2019]. Disponível em: http://www.cardiometro.com.br/anteriores.asp.

3. Marques SHB, Souza AC, Vaz AA, Pelegrini AHW, Linch GFC. Mortalidade por causas externas no Brasil de 2004 a 2013. Rev Baiana Saúde Pública. 2017;41(2):394-409.

4. Brasil. Banco de dados do Sistema Único de Saúde - DATASUS. Óbitos por causas externas. Brasília: Ministério da Saúde; 2019 [access in 9 jan 2021]. Available from: http://tabnet.datasus.gov.br/cgi/tabcgi.exe?sim/ cnv/ext10uf.def.

5. Tallo FS, Moraes Junior R, Guimarães HP, Lopes RD, Lopes AC. Atualização em reanimação cardiopulmonar: uma revisão para o clínico. Rev Soc Bras Clín Méd. 2012;10(3):194-200.

6. American Red Cross. Basic Life Support for healthcare providers handbook. Stamford: Staywell; 2015 [acesso em 10 set 2018]. Disponível em: https:// topguardtraining.com/wp-content/uploads/2018/01/BLS-Participant.pdf.

7. Hasselqvist-Ax I, Riva G, Herlitz J, Rosenqvist M, Hollenberg J, Nordberg P, et al. Early cardiopulmonary resuscitation in out-of-hospital cardiac arrest. N Engl J Med. 2015;372:2307-15.

8. Mauri R, Burkart R, Benvenuti C, Caputo ML, Moccetti T, Del Bufalo A, et al. Better management of out-of-hospital cardiac arrest increases survival rate and improves neurological outcome in the Swiss Canton Ticino. Europace. 2016;18:398-404.

9. Mejia CR, García-Saavedra MB, Benites-Flores IR, Ordinola-Calle DD, FailocRojas VE, Valladares-Garrido D, et al. Associated factors with knowledge of basic life support in medical students from nine Peruvian universities. Rev Mex Cardiol. 2016;27(4):148-55.
10. Silva DV, Jesus APS, Lima AA, Santos MSAS, Alves SL. Conhecimento de graduandos em enfermagem sobre suporte básico de vida. Rev Baiana Enferm. 2015;29(2):125-34.

11. Saquib SA, Al-Harthi HM, Khoshhal AA, Shaher AA, Al-Shammari AB, Khan $A$, et al. Knowledge and attitude about Basic Life Support and Emergency Medical Services amongst healthcare interns in University Hospitals: a cross-sectional study. Emerg Med Int. 2019;2019:1-8.

12. Tavares LFB, Bezerra IMP, Oliveira FR, Sousa LVA, Raimundo RD, Sousa EC, et al. Conhecimento de estudantes de graduação em ciências da saúde em testes objetivos sobre suporte básico de vida. J Human Growth Dev. 2015;25(3):297-306

13. Chew KS, Hashairi FM, Zarina ZI, Farid AWS, Yazid MNA, Hisamuddin NARN. A survey on the knowledge, attitude and confidence level of adult cardiopulmonary resuscitation among junior doctors in Hospital Universiti Sains Malaysia and Hospital Raja Perempuan Zainab II, Kota Bharu, Kelantan, Malaysia. Med J Malaysia. 2011;66(1):56-9.

14. Uhm DC, Hwang JY, Jun MH, Kim DO. Structural equation model of clinical nurses' willingness to perform Basic Life Support (BLS) in South Korea. Journal of the Korea Academia-Industrial Cooperation Society. 2016;7(2):290-8.

15. Willmore RD, Veljanoski D, Ozdes F, Stephens B, Mooney J, Crumley SG, et al. Do medical students studying in the United Kingdom have an adequate factual knowledge of basic life support? World J Emerg Med. 2019;10(2):75-80.

16. Santos MS, Toledo LV, Alves KR, Santana MMR, Ribeiro L, Diaz FBBS Conhecimento da equipe de enfermagem do setor de hemodiálise sobre o atendimento a parada cardiorrespiratória. HU Rev. 2017;43(3):375-81.

17. Oliveira SFG, Moreira SMBP, Vieira LL, Gardenghi G. Conhecimento de parada cardiorrespiratória dos profissionais de saúde em um hospital público: estudo transversal. Rev Pesqui Fisioter. 2018;8(1):101-9.

18. Zanesco C, Galvan J, Galvão N, Bordin D, Fadel CB. Conhecimento e segurança de universitários da área de ciências biológicas e da saúde sobre primeiros socorros. Rev Pesqui. 2020;12: 154-60.

19. Hung MSY, Chow MCM, ChuTTW, Wong PP, Nam WY, Chan VLK, et al. College students' knowledge and attitudes toward bystander cardiopulmonary resuscitation: a cross-sectional survey. Cogent Med. 2017;4(1):e1334408.

20. Dixe MACR, Gomes JCR. Conhecimento da população portuguesa sobre Suporte Básico de Vida e disponibilidade para realizar formação. Rev Esc Enferm USP. 2015;49(4):640-9.

21. Chehuen Neto JA, Bru IV, Pereira DR, Santos LG, Moraes SL, Ferreira RE Conhecimento e interesse sobre suporte básico de vida entre leigos. Int $J$ Cardiovasc Sci. 2016;29(6):443-52.

22. American Heart Association. Basic life support: instructors essentials faculty guide. 2018 [access in 8 jun 2019]. Available from: https:// ahainstructornetwork.americanheart.org/idc/groups/ahaecc-public/@ wcm/@ecc/documents/downloadable/ucm_499295.pdf. 